\title{
PROBLEMS OF FORMATION AND DIAGNOSTICS SCIENTIFIC WORLDWIDE OF FUTURE PHYSICS TEACHERS
}

\section{ПРОБЛЕМИ ФОРМУВАННЯ I ДІАГНОСТИКИ НАУКОВОГО СВІТОГЛЯДУ МАЙБУТНІХ УЧИТЕЛІВ ФІЗИКИ}

\author{
Olexandr SHKOLA, \\ Doctor of Pedagogical Sciences, \\ Associate Professor \\ Berdiansk State Pedagogical \\ University \\ 4 SchmidtaSt., Berdiansk, \\ Zaporizhzhia region, 71100
}

https://orcid.org/0000-0001-9946-446X

aleksandrshkola99@gmail.com

\author{
Олександр ШКОЛА,
доктор педагогічних наук, доцент \\ Олександр ШКОЛА,
доктор педагогічних наук, доцент
}

Original manuscript received: October 08, 2019

Бердянський державний

педагогічний університет

вул. Шмідта 4, м. Бердянськ,

Запорізька обл., 71100

Revised manuscript accepted: December 17, 2019

\begin{abstract}
The article is devoted to the theoretical and methodological aspects of solving the actual, complex and multifaceted problem of the creating of the scientific world view of pre service teachers of physics as a leading quality of personality, the basis of their professional competence. The author analyses the degree of the development of the problem of research in the philosophical, psychological and pedagogical literature, theory and practice of teaching physics; clarifies the essence and basic characteristics of the basic concepts: "worldview", "scientific worldview" of the individual. It is established that the core of the scientific worldview is the scientific picture of the world, which is the result of the integration of generalized images of the surrounding world of the individual sciences and forms the basis of thinking, conscious behaviour and human activity. In this context, the creating of ideological beliefs and beliefs does not automatically occur with the assimilation of subject knowledge within a certain discipline, but requires a separate purposeful and systematic approach of the whole pedagogical staff of the educational institution.

The author defines the basic components, didactic conditions, criteria and indicators of the levels of creating of the natural-scientific world view of pre-service teachers of physics, as well as forms and means of diagnostics, which are based primarily on students' study of general and theoretical physics. Educational and methodological complex, which includes a modular program of generalization of students' knowledge in the course of theoretical physics; a textbook for the study of theoretical material, problem solving, a collection of tests (which contain, among others, the issues of methodological and ideological nature) on the example of the course of "Thermodynamics and statistical physics" were developed and implemented in the educational process. The study of general and theoretical physics by pre-service teachers should take into account the principle of continuity on the basis of the creation of the most complete and holistic ideas about the modern world picture and its evolution; awareness of the content and structure of fundamental physical theories, their unity, multifunctionality and hierarchy according to


Серія: Педагогічні науки. - Вип.3. - Бердянськ : БДПУ, 2019. - 453 с.

certain spatial intervals and interactions.

Key words: personality worldview, scientific worldview, professional competence of physics teacher, physical picture of the world.

Вступ. На пріоритетне значення світоглядного аспекту фрізичної освіти, формування в молоді цілісного світорозуміння, сучасного наукового світогляду, навичок самоосвіти і критичного мислення вказано в Законах України “Про освіту”, “Про вищу освіту”, Державному стандарті базової і повної загальної середньої освіти, галузевому стандарті вищої освіти “Фізика”. У формуванні світоглядних уявлень і переконань людини фрізика посідає провідне місце невипадково, оскільки серед інших природничих наук саме вона займається вивченням властивостей, закономірностей, внутрішнього механізму перебігу різноманітних природних явищ, найбільш загальних і фундаментальних питань, що мають глибокий філософський і світоглядний зміст. Посилення світоглядної і методологічної спрямованості шкільного курсу фрізики та відповідної професійної підготовки майбутніх учителів фізики є дуже важливим, а в останній час - особливо актуальним, що підтверджується рядом обставин: зниженням рівня пізнавального інтересу школярів до вивчення природничих наук та відповідної базової підготовки студентів-першокурсників, різким зменшенням кількості абітурієнтів на відповідні педагогічні спеціальності закладів вищої освіти, зниженням якості фундаментальної підготовки майбутніх учителів фізики, проникненням релігійних ідей і псевдонаукової інформації в усі сфери суспільного життя, що має негативний вплив на масову свідомість, особливо сучасної молоді. Реальні освітні результати свідчать: рівень свідомості і системності знань значної кількості сучасних школярів з фізики $€$ невисоким, існують труднощі в оволодінні понятійним апаратом, "мовою" фізичної науки, "читанням" фізичних формул, застосуванням знань на практиці, висновками методологічного i світоглядного характеру, рефлексією власних розумових дій. У шкільний практиці часто реалізується лише емпіричний рівень узагальнення знань учнів, який відтворює переважно буденний досвід, що не відповідає сучасному рівню і методології фрізичної науки.

За результатами нашого опитування першокурсників-фізиків, присвячених питанням релігії і світогляду, у телекінез, телепатію, містику, гадання і чаклунство та інші дива сьогодення вірили в середньому $45 \%$ респондентів. Опитування бакалаврів-фрізиків під час державних екзаменів показало, що ці показники за період навчання зменшуються приблизно вдвічі. Актуальність розв'язання зазначеної проблеми підтверджується результатами анкетування вчителів фізики м. Бердянська і району, які до основних труднощів її успішного розв'язання відносять: 1) неоднозначність трактування самого поняття у науковій літературі; 2) відсутність чітких методичних рекомендацій, конкретних вправ методологічного i світоглядного характеру, відповідних засобів діагностики; 3) відсутністю завдань такого характеру серед інших на державному $3 \mathrm{HO}$ з фізики. Як наслідок, маємо труднощі у виконанні одного з найважливіших завдань загальноосвітньої школи - формуванні цілісного діалектико- 
матеріалістичного світогляду сучасних школярів. Фізична освіта в педагогічних університетах нині вимагає оновлення i розробки таких концептуальних підходів, за яких буде відбуватись цілеспрямоване, системне і послідовне фрормування природничо-наукового світогляду майбутніх учителів фрізики як провідної якості особистості, основи їх фахової компетентності, здатних ефективно працювати в сучасній загальноосвітній школі, сприяти розвитку інтелектуальних і творчих здібностей своїх учнів, формуванню їх наукового світогляду, культури мислення, навичок самоосвіти і самовдосконалення.

Аналіз сучасних публікацій, педагогічного досвіду колег, практики викладання курсів загальної і теоретичної фізики в університеті, досвіду роботи у складі приймальної і державних екзаменаційних комісій, на курсах підвищення кваліфрікації вчителів свідчить, що незважаючи на ґрунтовні наукові здобутки і практичні напрацювання минулих років проблема формування наукового світогляду учнів у навчанні фрізики (а відповідно й майбутніх учителів фізики) залишається актуальною, багатогранною та однією з найскладніших. Зрозуміло, що фрормування світоглядних уявлень і переконань людини не відбувається автоматично із засвоєнням предметних знань у рамках певної дисципліни, а потребує окремого цілеспрямованого і системного підходу усього педагогічного колективу освітнього закладу. Отже, метою статmі $\epsilon$ висвітлення теоретико-методичних підходів розв'язання складної i багатогранної проблеми формування наукового світогляду майбутніх учителів фізики як провідної якості особистості, невід'ємного компоненту їх фундаментальної та професійної підготовки, основи фахової компетентності.

Методи та методики дослідження: аналіз державних нормативних освітніх документів, наукових i навчально-методичних праць, державних стандартів освіти, навчальних планів та освітньо-професійних програм підготовки майбутніх учителів фрізики; спостереження, анкетування, тестування, бесіди зі студентами і викладачами - з метою з'ясування стану вивченості, актуальних питань і шляхів розв'язання досліджуваної проблеми, уточнення понятійного апарату дослідження; порівняння та узагальнення - для систематизації результатів дослідження, формулювання висновків і визначення напрямів подальших наукових розвідок.

Результати та дискусії. Важливою передумовою розв'язання зазначеної проблеми $€$ чітке трактування базового терміну "світогляд особистості". Оскільки він є предметом вивчення не лише філософрії, але й ряду інших наук (педагогіки, психології, наукознавства, мистецтвознавства та ін.), не існує його однозначного розуміння: комплексний, багатогранний характер цього поняття зумовлює різноманітність трактувань сутності. Найчастіше світогляд людини розглядають як систему поглядів на об'єктивний світ і своє місце в ньому, а також обумовлені цими поглядами життєві принципи, цінності і переконання, що визначають спрямованість її мислення, поведінки і діяльності. За результатами наукових пошуків на сьогодні з'ясовано його основні характеристики: компоненти, рівні, функції, критерії класифікації (Хайруліна, 2011). Відповідно до того, які знання людина застосовує для пояснення навколишнього світу, розрізняють 
науковий і ненауковий світогляд. Науковий світогляд - своєрідний феномен як особистісного, так і суспільного життя людини, що включає в себе взаємопов'язані об'єктивні (наукова картина світу, фрілософські ідеї, методологічні і технічні знання) і суб'єктивні (цінності, погляди, переконання) компоненти. 3 урахуванням аспектів дійсності (природа, суспільство, людина, мислення) можна вважати, що вивчення курсу фізики сприяє формуванню певних системних філософські осмислених знань про природу та процеси її пізнання, тобто формуванню більшою мірою природничо-наукового аспекту світогляду.

Аналіз літературних джерел свідчить, що проблема формування наукового світогляду школярів у дидактиці фізики не є новою, вона інтенсивно досліджується протягом останніх 60 років (Савченко, 2011). Сьогодні існує багато науково-методичних матеріалів, в яких глибоко розкрито й проаналізовано їі різні теоретичні та методологічні аспекти: розкриття діалектико-матеріалістичного характеру процесу пізнання природи та науково-атеїстичне виховання учнів (А. Вещицький, Ю. Дік, Д. Пеннер, О. Пьоришкін, В. Разумовський та ін.); відображення у змісті шкільного курсу фрізики методології і методів наукового пізнання, у тому числі принципу історизму (Г. Голін, Л. Рєзніков, О. Сергєєв, Б. Спаський, І. Туришев та ін.); генералізація змісту навколо фундаментальних фізичних теорій як елементів сучасної фрізичної картини світу (О. Бугайов, П. Знаменський, С. Каменецький, В. Мултановський, А. Усова та ін.); формування цілісності, системності знань школярів на основі реалізації міжпредметних зв'язків, у тому числі й у позаурочний час у фрормі факультативних занять, гуртків, фрізичних вечорів, екскурсій (Н.Звєрєва, Л. Зоріна, І. Ланіна, Н. Родіна, Н. Тализіна та ін.); розкриття ціннісного аспекту наукових знань та процесу їх здобуття на уроках фрізики (І. Авдєєва, Р. Аканова, Л. Тарасов, С. Чандаєва та ін.).

Проблемі цілісності знань учнів у навчанні фізики та формування їх наукового світогляду присвячені докторські дисертації В. Мултановського, В. Мощанського, С. Гончаренка, В. Ільченко. Згідно В. Мултановського, завдання формування наукового світогляду учнів може бути успішно вирішене в процесі послідовного засвоєння основ фундаментальних фрізичних теорій як складових сучасної фрізичної картини світу, оскільки “призначення теорії - не лише досягнений нею результат мислення, але й сам вироблений нею спосіб/стиль мислення". За В.Мощанським, основними компонентами розв'язання зазначеної проблеми $€$ : а) діалектикоматеріалістичне трактування природних явищ; б) формування знань про процес наукового пізнання; в) формування наукового стилю мислення. С. Гончаренко і В. Ільченко вважать основним шляхом розв'язання зазначеної проблеми послідовну систематизацію та узагальнення попередньо сформованих в учнів фундаментальних понять, принципів, законів і теорій у локальні наукові картини світу та подальшу інтеграцію останніх в єдину природничо-наукову картину світу. Протягом останніх трьох десятиліть світоглядний аспект шкільної фізичної освіти знайшов своє логічне продовження у дисертаціях Н. Бургун, О. Васєєвої, В. Жешко, 
В. Ковальчука, М. Растьогіна, М. Червоного та ін., присвячених переважно дослідженню окремих складових проблеми: формуванню ціннісносвітоглядних орієнтацій, екологічного та методологічного компонентів; засобами узагальнення знань, впливу освітнього середовища, на основі міжпредметних зв'язків, використання принципу історизму.

На думку більшості вітчизняних учених-методистів, загальноосвітня вимога формування в учнів і студентів цілісних, системних знань $€$ логічним відображенням принципу єдності природи та основної тенденції розвитку сучасної фрізичної науки - прагнення до єдності знань про навколишній світ. При цьому становлення наукового світогляду школярів і майбутніх учителів фрізики передбачає передусім систематизацію та узагальнення предметних знань навколо фундаментальних наукових ідей, принципів, законів і теорій, що можна зробити найбільш оптимально шляхом формування в їх свідомості найповніших і цілісних уявлень про сучасну фрізичну картину світу (ФКС). Останнє потребує ознайомлення учнів/студентів з провідними фрілософрськими принципами (матеріальної єдності і пізнаванності світу, нерозривності матерії та її руху, простір і час як форми існування матерії, діалектичний характер і нескінченність процесу пізнання), що складають її основу, та наступну трансформацію зазначених фрілософських ідей у їх погляди і переконання.

У підготовці майбутніх учителів фізики цей процес відбувається протягом усього періоду навчання в педагогічному університеті, але не всі дисципліни на нього впливають однаково. Курс загальної фрізики, як відомо, має переважно експериментальний характер; використання у його рамках індуктивного підходу у пізнанні фізичної реальності виступає лише першим етапом фрундаментальної підготовки, становлення наукового світогляду майбутніх учителів фрізики. Застосування у науці і навчальному пізнанні дедуктивного підходу передбачає перехід 3 емпіричного рівня усвідомлення закономірностей навколишнього світу на теоретичний. Тому особливе положення у розв'язанні зазначеної проблеми належить курсу теоретичної фрізики, який завершує фундаментальну підготовку майбутніх учителів фрізики в педагогічному університеті, зумовлюючи таким чином його провідну освітню мету: формування найповніших і цілісних уявлень про сучасну ФКС та ії еволюцію. Студенти мають усвідомлювати зміст і структуру фундаментальних фрізичних теорій, характер взаємозв'язків між елементами знань цих теорій. Саме нерозуміння цих зв'язків часто ускладнює перебудову “множинності" знань у "систему", що неминуче приводить до перевантаження пам'яті.

У зв'язку з цим на першому етапі нашої роботи на основі аналізу навчальних планів підготовки майбутніх учителів фрізики було з'ясовано місце та "питому вагу" спеціальних фрахових дисциплін (передусім курсів загальної і теоретичної фізики), а також динаміку зміни навчальних годин на їх вивчення протягом останніх 30 років, яка, до речі, має позитивний характер $(15 \rightarrow 19 \%$ та $10 \rightarrow 12 \%$ відповідно). Узагальнення наукових праць дозволило з'ясувати основні компоненти та дидактичні умови фрормування наукового 
Серія: Педагогічні науки. - Вип.3. - Бердянськ : БДПУ, 2019. - 453 с.

світогляду майбутніх учителів фізики. До першого відносимо: 1) формування найповніших і цілісних уявлень про сучасну ФКС та її еволюцію на основі оволодіння сутністю фундаментальних фрізичних теорій; 2) фрормування знань про процес і методи наукового пізнання; 3) оволодіння понятійним апаратом і “мовою" фрізичної науки; 4) здобуття досвіду самостійної практичної діяльності, що ілюструє справедливість і цінність набутих студентами світоглядних знань у розв'язанні різноманітних фрізичних завдань, тобто трансформація їх поглядів і уявлень у переконання. Другий складають такі положення: реалізація у навчанні принципу науковості (відповідності змісту і методів навчання сучасному рівню і методології фізичної науки); активна пізнавальна діяльність із засвоєння і застосування на практиці елементів знань (науковий фракт, фрізичне явище, величина, модель, закон); розкриття діалектико-матеріалістичного характеру фізичних явищ, виділення у змісті фізичних теорій провідних світоглядних ідей та їх осмислення з узагальнених філософських позицій; реалізація у навчанні міжпредметних зв'язків і принципу історизму, що сприятиме розкриттю єдності наукових знань, “драми ідей”; формування системи гуманістичних цінностей студентів, критичного мислення у сприйнятті нової інформації, виховання викладачем на власному прикладі високих моральних якостей; національно-патріотичне виховання; системний моніторинг рівня світоглядної підготовки студентів.

Аналіз літературних джерел свідчить, що незважаючи на широкий спектр теоретичних матеріалів стосовно шляхів системної діагностики наукового світогляду особистості, єдиного підходу з цього питання сьогодні не існує. Кожен автор визначає свої характеристики-індикатори та критерії сформованості, використовуючи для цього, як правило, два основних підходи: поелементний (В. Андрущенко, Б. Кедров, І. Лернер, В. Платонов, В. Сластьонін, В. Мощанський, В. Мултановський та ін.): спеціальні/предметні знання, діалектико-матеріалістичне трактування природних явищ, науковий стиль мислення, характер оціночних суджень за змістом, повнотою і самостійністю та ін.; блочний (П. Атаманчук, О. Бугайов, О. Ляшенко, Н. Менчинська, Е. Моносзон, В. Черноволенко, В. Шинкарук та ін.): пізнавальний (світосприйняття, світорозуміння, світовідношення); інтелектуальний (система світоглядних знань про закономірності розвитку природи, суспільства, мислення); емоційновольовий (почуття впевненості, відповідальності, боргу, патріотизму); мотиваційний (мотиви, інтереси, ідеали, емоційні характеристики); діяльнісно-практичний (поведінка та активність особистості); ціннісний; рефлексивний та ін.

Приймаючи до уваги зазначені підходи, а також спираючись на власний педагогічний досвід, нами запропоновано критерії і показники рівнів сформованості наукового світогляду майбутніх учителів фрізики, а також форми і засоби діагностики, що базуються на вивченні ними передусім курсів загальної і теоретичної фізики. Зрозуміло, що використання пропонованого діагностичного інструментарію потребує цілеспрямованого та системного підходу. На основі вищевикладеного у контексті дослідження було 
розроблено модульну програму узагальнення знань студентів з курсу теоретичної фізики, в якій окрім обов'язкових компонентів, на основі структурування елементів знань визначено і конкретизовано зміст науковотеоретичної і практично-діяльнісної складових фрахової компетентності студентів для кожного змістового модулю дисципліни. Програма має вигляд таблиці. У першій колонці наведено назви тем модулю; друга містить навчальний матеріал модулю, що підлягає засвоєнню та узагальненню (перелік фрізичних понять, величин, явищ, ефектів, методів, дослідів, моделей, законів, принципів, постулатів, теорем, рівнянь); у третій колонці представлено відповідно теоретичні і практичні завдання, рівень складності яких вимагає опрацювання студентами під керівництвом викладача (завдання представлені у формі: пояснити, зобразити і проаналізувати, моделювати, вивести і визначити, зробити висновки методологічного і світоглядного характеру); четверта містить перелік основних знань і умінь, які студенти мають опанувати самостійно. Представлені в такому вигляді узагальнення дозволяють відмежувати основний навчальний матеріал, що має фундаментальне, найбільш важливе професійно-педагогічне значення, від допоміжного та представити його як певну систему.

На основі вищевикладеного до останнього розділу курсу теоретичної фізики у робочій програмі нами було внесено підсумковий навчальний модуль, який акцентує увагу студентів на проблемі світоглядної підготовки сучасних школярів та зорієнтований на систематизацію та узагальнення їх знань на рівні сучасної ФКС. Його зміст складають такі питання: сутність та основні характеристики понять “світогляд особистості”; “науковий світогляд”, дидактичні умови формування, критерії та показники рівнів сформованості, форми і засоби діагностики; узагальнені плани вивчення елементів знань (науковий факт, фізичне явище, величина, модель, принцип, закон, теорія); зміст і структура фундаментальних фрізичних теорій, сучасна ФКС та її еволюція. У рамках цього модулю студенти уточнюють і систематизують знання стосовно змісту і структури фундаментальної фізичної теорії як цілісного об'єкту (основа, ядро, наслідки), їх основні модельні уявлення, основні поняття, принципи і закони, що складають найзагальніші "клітинки" фізичного пізнання, які повинні бути в центрі уваги під час вивчення окремих розділів курсу теоретичної фрізики.

Використання студентами узагальнених планів вивчення елементів знань як певного роду зразків/схем "руху думки" допомагає відтворити у свідомості цілісні уявлення про навчальний об'єкт, сприяє оволодінню ними “мовою” фізичної науки та загальним підходом щодо їх формування та використання у навчально-пізнавальній діяльності. Звичайно, найповніші та цілісні уявлення про сучасну ФКС (вихідні філософські ідеї, фундаментальні теорії, основні принципи) студенти можуть одержати тільки наприкінці курсу теоретичної фрізики, після того як будуть узагальнені та приведені в систему їх знання. До того часу контури сучасної ФКС окреслити неможливо через нестачу відповідних знань студентів. Тому після вивчення класичної механіки можна говорити 
лише про систематизацію та узагальнення їх знань на рівні механістичної картини світу, електродинаміки - електромагнітної, квантової механіки квантово-польової, після вивчення термодинаміки і статистичної фрізики розкривати основні аспекти сучасної еволюційно-синергетичної парадигми наукових досліджень. 3 нашої точки зору, усвідомлення студентами структури і змісту сучасної ФКС та її еволюції сприятиме не тільки розумінню ними внутрішньої логіки розвитку фрізичної науки, методології наукового пізнання, але й оволодінню історичним підходом до викладання фізики в загальноосвітній школі, формуванню системи гуманістичних цінностей, національно-патріотичному вихованню.

У контексті дослідження розроблено і впроваджено в освітній процес навчально-методичний комплекс, що включає в себе типову (Шут, Школа, 2014) і модульну програму узагальнення знань студентів з курсу теоретичної фрізики; навчально-методичні посібники 3 вивчення теоретичного матеріалу, розв'язування задач, збірник тестових завдань (що містить серед інших питання методологічного і світоглядного характеру) на прикладі окремого (завершального) розділу курсу “Термодинаміка і статистична фрізика".

Висновки. Таким чином, вивчення майбутніми вчителями курсів загальної і теоретичної фізики має відбуватися з урахуванням принципу наступності, з єдиних позицій, методично поєднаних спільною ідеєю щодо формування найповніших і цілісних уявлень про сучасну ФКС та їі еволюцію; усвідомлення змісту і структури фундаментальних фрізичних теорій, їх єдності, багатофункціональності та ієрархічності відповідно до певних просторових інтервалів і взаємодій. Перспективи дослідження вбачаємо у розробці засобів системної і неперервної діагностики формування предметної, світоглядної і методологічної складових фахової компетентності майбутніх учителів фізики за результатами навчання курсів загальної і теоретичної фрізики, що свідчитиме про відповідність якості їх фундаментальної підготовки державним нормативним освітнім вимогам.

\section{Література}

1. Методика навчання фізики у старшій школі / [за ред. В.Ф. Савченка]. - К. : Академвидав, 2011. - 294 с.

2.Теоретична фізика. Програма навчальної дисципліни підготовки фахівців освітньо-кваліфікаційного рівня “бакалавр" напряму 6.040203 Фізика* для студентів вищих педагогічних закладів освіти : навч. видання / [уклад. М.І.Шут, О. В. Школа]. - Бердянськ : БДПУ, 2014. - 70 с.

3.Хайрулліна Ю.О. Світоглядна культура особистості: структурнофункціональний аналіз : монографрія / Ю. О. Хайрулліна. - К. : Вид-во НПУ ім. М. П. Драгоманова, 2011. - 235 с.

4.Школа О. В. Теоретико-методичні засади навчання теоретичної фрізики майбутніх учителів фрізики : монографія / О.В.Школа. - Бердянськ : Видавець О. В. Ткачук, 2015. - 381 с.

\section{References}

1. Metodyka navchannia fizyky u starshii shkoli / [za red. V.F. Savchenka]. K. : Akademvydav, 2011. - 294 s.

2. Teoretychna fizyka. Prohrama navchalnoi dystsypliny pidhotovky fakhivtsiv 
osvitno-kvalifikatsiinoho rivnia "bakalavr" napriamu 6.040203 Fizyka* dlia studentiv vyshchykh pedahohichnykh zakladiv osvity : navch. vydannia / [uklad. M. I. Shut, O. V. Shkola]. - Berdiansk : BDPU, 2014. - $70 \mathrm{~s}$.

3. Khairullina Yu. O. Svitohliadna kultura osobystosti: strukturno-funktsionalnyi analiz : monohrafiia / Yu. O. Khairullina. - K. : Vyd-vo NPU im. M. P. Drahomanova, 2011. - $235 \mathrm{~s}$.

4. Shkola O. V. Teoretyko-metodychni zasady navchannia teoretychnoi fizyky maibutnikh uchyteliv fizyky : monohrafiia / O. V. Shkola. - Berdiansk : Vydavets O. V. Tkachuk, 2015. - $381 \mathrm{~s}$.

\section{АНОТАЦІЯ}

Стаття присвячена висвітленню теоретико-методичних аспектів розв'язання актуальної, складної і багатогранної проблеми формування наукового світогляду майбутніх учителів фрізики як провідної якості особистості, основи їх фахової компетентності. Проаналізовано ступінь розробки проблеми дослідження у фрілософрській і психолого-педагогічній літературі, теорії і практиці навчання фрізики; з'ясовано сутність та основні характеристики базових понять: “світогляд", “науковий світогляд" особистості. Встановлено, що ядром наукового світогляду $\epsilon$ наукова картина світу, що виступає результатом інтеграції узагальнених образів навколишнього світу окремих наук та складає основу мислення, свідомої поведінки і діяльності людини. У зв'язку з цим фрормування світоглядних уявлень і переконань не відбувається автоматично із засвоєнням предметних знань у рамках певної дисципліни, а потребує окремого иілеспрямованого і системного підходу всього педагогічного колективу освітнього закладу.

Визначено основні компоненти, дидактичні умови, критерії і показники рівнів сформованості природничо-наукового світогляду майбутніх учителів фрізики, а також форми і засоби діагностики, що базуються на вивченні ними передусім курсів загальної $і$ теоретичної фрізики. Розроблено $і$ впроваджено в освітній процес навчально-методичний комплекс, що включає в себе модульну програму узагальнення знань студентів з курсу теоретичної фрізики; навчально-методичні посібники з вивчення теоретичного матеріалу, розв'язування задач, збірник тестових завдань (що містить серед інших питання методологічного $i$ світоглядного характеру) на прикладі окремого (завершального) розділу курсу "Термодинаміка і статистична фрізика". Вивчення майбутніми вчителями курсів загальної $і$ теоретичної фрізики має відбуватися $з$ урахуванням принципу наступності, з єдиних позицій, методично поєднаних спільною ідеєю щодо формування найповніших і иілісних уявлень про сучасну фрізичну картину світу та іï еволюцію; усвідомлення змісту і структури ффундаментальних фрізичних теорій, їх єдності, багатофрункціональності та ієрархічності відповідно до певних просторових інтервалів і взаємодій.

Ключові слова: світогляд особистості, науковий світогляд, фахова компетентність учителя фрізики, фрізична картина світу. 